\title{
ANALISIS KESULITAN PEMAHAMAN KONSEP PADA MATERI TITRASI ASAM BASA SISWA SMA
}

\author{
Hasan Marzuki, Resti Tri Astuti \\ Universitas Islam Negeri Raden Fatah Palembang \\ E-mail: hasanmarzuki_uin@radenfartah.ac.id
}

\begin{abstract}
Abstrak: Penelitian ini bertujuan untuk mengetahui kesulitan pemahaman konsep pada materi titrasi asam basa siswa SMA. Penelitian ini menggunakan metode deskriptif dengan data hasil penelitian diperoleh dari hasil tes siswa. Instrumen yang digunakan yaitu tes uraian, wawancara dan dokumentasi tentang materi titrasi asam basa. Penelitian ini dilakukan di SMA Percontohan UPI dengan subjek sebanyak 30 orang siswa SMA Kelas XII IPA yang telah mempelajari materi titrasi asam basa. Kesulitan pemahaman konsep yang dialami oleh siswa yaitu siswa kesulitan dalam menjelaskan pemilihan indikator sebanyak 53,33\%, siswa kesulitan dalam menuliskan persamaan dan menyetarakan persamaan reaksi asam sulfat dan natrium hidroksida sebanyak 56,65\%, siswa kesulitan dalam menentukan konsentrasi asam yang bervalensi dua sebanyak 70,00\% dan 10,00\% kesalahan siswa dalam menentukan konsentrasi asam dan basa bervalensi satu. Siswa kesulitan dalam $86,66 \%$ siswa tidak dapat menentukan jenis titrasi berdasarkan kurva dan siswa kesulitan dalam menentukan jenis zat pada setiap daerahsebesar 80,00\%. Faktor penyebab kesulitan pemahaman konsep yang dialami siswa disebabkan oleh cara mengajar guru dan siswa itu sendiri.
\end{abstract}

Kata kunci: Kesulitan, pemahaman konsep, titrasi asam basa.

\section{PENDAHULUAN}

Ilmu kimia merupakan salah satu rumpun ilmu sains yang mempelajari tentang sifat materi, struktur materi, perubahan materi dan energi yang menyertai reaksi.Dalam mempelajari ilmu kimia, siswa harus memahami konsep-konsep kimia dengan benar. Menurut Arifin (2003) pemahaman adalah suatu kemampuan yang dimiilki siswa untuk mengubah, mengadakan interpretasi dan mengeksplorasi. Dalam memahami konsep kimia tidak bisa dipisahkan antara satu dengan yang lainnya dikarenakan konsep kimia saling berkaitan satu dengan lainnya. Hal ini akan menjadikan kesulitan belajar siswa dalam mengerjakan tugas-tugas yang diberikan. Menurut Bachelard dan Piaget dalam Brousseau (2002) kesulitan belajar adalah kesalahan-kesalahan yang tidak menentu dan tidak terduga yang diperoleh siswa pada suatu proses dalam memaknai pengetahuan.

Kesulitan siswa dalam mempelajari ilmu kimia sangat mungkin dikarenakan siswa tidak memahami konsep-konsep dasar yang ada dengan benar, sehingga siswa mengalami kesulitan dalam memahami konsep-konsep selanjutnya (Nakhleh, 1992). Kesulitan belajar apabila tidak segera diatasi, maka semakin sulit bagi siswa untuk memahami materi kimia selanjutnya. Salah satu materi yang sulit dipahami adalah materi titrasi asam basa. Materi titrasi asam basa merupakan materi yang sulit bagi kebanyakan siswa karena bersifat abstrak. Menurut Sheppard (2006), siswa menggambarkan proses netralisasi sebagai pencampuran fisika dari asam dan basa yang tidak menghasilkan produk dan tidak memiliki persamaan reaksi. Beberapa siswa menjelaskan kurva titrasi pada waktu sebelum titik ekuivalen, pada titik ekuivalen, dan setelah titik ekuivalen merupakan sifat yang mendasar untuk interaksi antara asam dan basa yang tidak bereaksinya spesi-spesi kimia. Oleh karena itu untuk mengetahui kesulitan siswa dalam memahami materi titrasi asam basa diperlukan tes. Tes diberikan kepada siswa yang telah mempelajari materi titrasi asam basa.Tujuan dari penelitian ini adalah untuk mengetahui konsep-konsep apa saja yang menjadi kesulitan siswa pada materi titrasi asam basa. 


\section{METODOLOGI PENELITIAN}

Penelitian ini merupakan penelitian dengan metode deskriptif. Peneliti mendeskripsikan kesulitan pemahaman konsepyang dialami oleh siswa. Berdasarkan jawaban siswa dapat diketahui apakah siswa dapat memahami materi atau sekedar menebak jawaban pada soal yang dituntut untuk memberikan alasan sehingga dapat diketahui tingkat pemahaman konsep siswa pada materi titrasi asam basa. Subjek dalam penelitian ini siswa kelas XII IPA sebanyak 30 orang yang telah mempelajari materi titrasi asam basa padatahun ajaran 2014/2015. Instrumen yang digunakan meliputi tes uraian, wawancara semi terstruktur, dan dokumentasi. Tes diberikan untuk mengetahui kesulitan yang dialami siswa dalam memahami konsep pada materi titrasi asam basa. Tes yang diberikan berupa tes bentuk uraian. Wawancara semi terstruktur dilakukan untuk mendapatkan data yang sifatnya lebih mendalam untuk mengetahui karakteristik kesulitan belajar siswa pada materi titrasi asam basa, faktor yang menyebabkan kesulitan belajar siswa dan mengetahui proses pembelajaran yang telah dilakukan guru dalam mengajar materi titrasi asam basa. Dokumentasi berasal dari RPP, sumber ajar guru mengenai materi titrasi asam basa.

\section{HASIL DAN PEMBAHASAN}

Berdasarkan hasil penelitian ini diperoleh kesulitan pemahaman konsep pada materi titrasi asam basa. Deskripsi antara kesulitan belajar yang dialami siswa dijabarkan dalam penjelasan dibawah ini.

\section{Indikator Titrasi Asam Basa}

Pada soal menentukan indikator titrasi asam basa, siswa diberikan gambar trayek $\mathrm{pH}$ yang menuntut siswa dapat menentukan indikator titrasi pada larutan basa lemah dengan larutan asam kuat dan alasan pemilihan indikator. Berdasarkan analisis jawaban sebanyak 53,33\% siswa salah dalam menjelaskan pemilihan indikator. Kesalahan yang dilakukan oleh siswa dapat dilihat pada gambar 1.

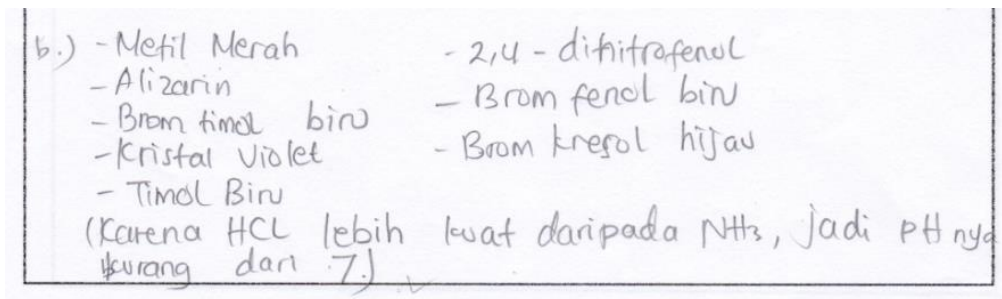

Gambar 1. Kesalahan Dalam Memberikan Alasan

Berdasarkan jawaban tersebut, menunjukkan bahwa siswa salah dalam memberikan alasan. Siswa menanggap bahwa asam atau basa yang bersifat lebih lemah akan menunjukkan titik ekuivalen berada pada $\mathrm{pH}$ kurang dari 7. Ini menunjukkan bahwa siswa kesulitan dalam memahami materi titrasi asam basa pada konsep menentukan indikator titrasi asam basa. Sheppard (2006) menyatakan bahwa siswa kebanyakan menganggap bahwa netralisasi merupakan sebuah proses dominasi asam terhadap basa dimana asam lebih kuat dari basa.

\section{Menuliskan Persamaan Reaksi}


Siswa diminta menuliskan persamaan reaksi dan menyetarakan koefisien reaksi antara asam sulfat dan natrium hidroksida. Hasil penelitian masih banyak siswa yang kesalahan dalam menuliskan persamaan reaksi dan menyetarakan koefisien reaksi.Sebanyak $56,67 \%$ siswa tidak bisa menuliskan persamaan dan menyetarakan persamaan reaksi asam sulfat dan natrium hidroksida. Kesalahan jawaban siswa dapat dilihat pada gambar 2 berikut.

$$
\text { A. } \mathrm{H}_{2} \mathrm{SO}_{4}+\mathrm{NaOH} \rightarrow \mathrm{NaSO}_{4}+2 \mathrm{H}_{2} \mathrm{O}
$$

Gambar 2. Kesalahan Dalam Menuliskan \& Menyetarakan Hasil Reaksi

Berdasarkan jawaban siswa, siswa tidak mempertimbangkan jumlah muatan dari $\mathrm{SO}_{4}$. Pemahaman konsep yang dimiliki siswa masih sangat rendah. Hal ini dikarenakan masih banyaknya kesalahan siswa sedangkan materi mengenai persamaan reaksi dan cara menyetarakan sudah dipelajari dikelas X SMA.

\section{Konsentrasi Titrasi Asam Basa}

Siswa diberikan 2 soal dalam menentukan konsentrasi titrasi asam basa. Pertama siswa menghitung konsentrasi asam bervalensi dua yang dititrasi dengan basa bervalensi satu yaitu untuk titrasi $\mathrm{H}_{2} \mathrm{SO}_{4}$ dengan $\mathrm{NaOH}$. Kedua, siswa diminta menghitung konsentrasi asam dan basa bervalensi satu yaitu titrasi $\mathrm{HCl}$ dengan $\mathrm{NaOH}$. Hasil penelitian menunjukkan sebanyak $70,00 \%$ kesalahan siswa dalam menentukan konsentrasi asam yang bervalensi duasedangkan hanya 10,00\% kesalahan siswa dalam menentukan konsentrasi asam dan basa bervalensi satu. Kesalahan siswa untuk perhitungan konsentrasi asam bervalensi dua dapat dilihat pada gambar 3 berikut.

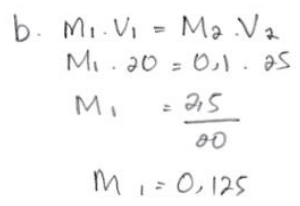

\section{Gambar 3. Kesalahan Dalam Menentukan Konsentrasi Titrasi Asam Basa}

Berdasarkan jawaban siswa, menunjukkan bahwa kesalahan dalam perhitungan. Siswa belum memahami konsep titrasi mengenai makna satu ekuivalen yang menunjukkan banyaknya asam yang bereaksi dengan $1 \mathrm{~mol} \mathrm{OH}^{-}$dan sebaliknya. Konsep yang dipahami siswa hanya sebatas rumus dan belum bisa menerapkan dalam perhitungan untuk asam yang bervalensi 2 . Kesulitan siswa dalam memahami ilmu kimia dapat bersumber

\section{Jenis Titrasi Asam Basa Berdasarkan Kurva.}

Siswa diberikan soal berupa 3 jenis kurva titrasi asam basa. Pertama, siswa diberikan kurva yang menunjukkan kurva titrasi asam kuat dengan basa kuat. Kedua,siswa diberikan kurva titrasi basa lemah dengan asam kuat dan ketiga yaitu kurva asam lemah dengan basa kuat. Hasil analisis jawaban siswa persentase sebesar 86,66\% siswa tidak dapat menentukan jenis titrasi berdasarkan kurva. Kesalahan siswa dalam menentukan jenis titrasi berdasarkan kurva dapat dilihat pada gambar 4 berikut.

- Kurva 1: titrasi asam kuat dengan basa kuat

$\rightarrow$ Kurva 2: titrasiasam kuat dengan basa lemah
-) kurva 3: "lemah " " " " 
Gambar 4. Kesalahan Siswa Dalam Menentukan Jenis Titrasi Asam Basa Berdasarkan Kurva

Berdasarkan jawaban siswa, menunjukkan bahwa kesalahan dalam menentukan jenis titrasi berdasarkan kurva. Konsep yang dipahami siswa hanya sebatas jenis titrasi, tanpa memiliki pemahaman mengenai cara memahami konsep kurva dalam titrasi.

\section{Mengindetifikasi Jenis Zat/Larutan PadaSetiap Daerah Kurva Titrasi Asam Basa}

Siswa diberikan soal dalam menentukan jenis zat pada daerah yang sudah ditentukan pada kurva titrasi asam asetat dan natrium hidroksida. Terdapat 4 daerah dalam kurva yaitu daerah 1 merupakan daerah sebelum penambahan $\mathrm{NaOH}$. Daerah 2 yaitu sebelum mencapai titik ekuivalen. Daerah 3 yaitu titik ekuivalen dan daerah 4 yaitu setelah titik ekuivalen. Persentase sebesar $80 \%$ siswa tidak dapat menentukan jenis zat pada setiap daerah. Kesalahan siswa dapat dilihat pada gambar 5 berikut.

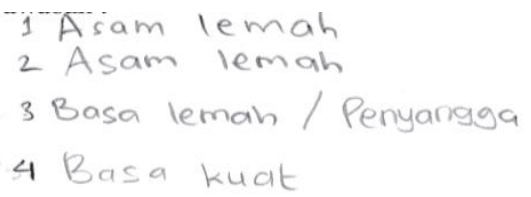

Gambar 5. Kesalahan Siswa dalam Menentukan Jenis Zat berdasarkan Daerah Kurva Titrasi

Jawaban siswa menunjukkan bahwa siswa belum bisa membedakan asam kuat/lemah atau basa kuat/asam lemah. Konsep dalam membedakan sifat asam atau basa merupakan materi asam basa yang sebelumnya telah dipelajari sebelum mempelajari materi titrasi asam basa. Konsep ini merupakan konsep prasyarat yang seharusnya telah dipahami dan dikuasai oleh siswa. Berdasarkan hasil identifikasi kesulitan belajar siswa pada materi titrasi asam basa menunjukkan bahwa masih banyaknya siswa yang mengalami kesulitan pada materi titrasi asam basa. Materi titrasi asam basa merupakan materi yang telah siswa pelajari ketika duduk di kelas XI SMA. Ini berhubungan dengan retensi siswa. Retensi merupakan kemampuan untuk mengingat kembali materi yang telah dipelajari. Menurut Windura (2010) akan terjadinya penurunan daya ingat dengan berjalannya waktu. Namun materi pelajaran yang bermakna akan lebih mudah diingat siswa dibandingkan dengan materi yang tidak bermakna, benda yang jelas dan kongkret akan lebih mudah diingat siswa dibanding dengan yang bersifat abstrak. Retensi akan lebih baik untuk materi yang bersifat kontekstual. Hal ini menunjukkan bahwa dengan pembelajaran yang bermakna, benda yang jelas dan kongkret dan materi yang bersifat kontekstual dapat membuat daya ingat siswa lebih baik.

Faktor-Faktor Siswa kesulitan Dalam Memahami Konsep pada Materi Titrasi Asam Basa 
Berdasarkan hasil wawancara siswa, beberapa faktor yang menyebabkan siswa mengalami kesulitan dalam memahami materi titrasi asam basa yaitu siswa mengalami kebigungan dalam menentukan indikator berdasarkan trayek $\mathrm{pH}$ karena belum pernah diberikan contoh soal atau latihan dalam menentukan indikator, siswa lupa cara dalam membuat persamaan reaksi dan cara menyetarakan reaksi serta siswa tidak ada keinginan untuk bertanya dikarenakan tidak ada siswa lainnya yang ingin bertanya, siswa tidak mempertimbangkan jumlah valensi setiap asam atau basa, siswa bigung dalam menentukan jenis titrasi berdasarkan kurva. Siswa beranggapan semua jenis larutan yang dititrasi adalah asam dan zat yang menjadi pentitrasi adalah basa. Siswa tidak memahami konsep dalam menentukan jenis zat karena hanya ada kurva sedangkan yang diberikan soal adalah menuntut siswa memahami zat setiap daerah.

Berdasarkan hasil dokumentasi RPP guru menunjukkan metode yang digunakan masih memberikan ceramah dan latihan soal yang ada di sumber belajar siswa. Hal ini diperkuat dengan hasil wawancara guru mengenai cara memberikan materi titrasi asam basa, guru mengatakan bahwa materi titrasi asam basa bisa diberikan secara sekilas saja karena materinya sedikit, kegiatan pembelajaran dapat dilakukan dengan pemberian soal latihan dan tidak diperlukan kegiatan praktikum. Sejalan dengan hasil wawancara yang dilakukan dengan siswa menunjukkan bahwa metode yang digunakan guru masih sebatas ceramah dan latihan soal, guru tidak melakukan praktikum sederhana yang dapat dilakukan oleh siswa. Berdasarkan hasil wawancara tersebut, dapat disimpulkan pembelajaran guru belum bermakna, dikarenakan hanya sebatas memberikan penjelasan dan latihan soal, sehingga pemahaman konsep siswa terhadap materi titrasi asam basa masih rendah. Materi titrasi asam basa dapat dilakukan melalui demonstrasi guru, atau dapat melibatkan siswa secara langsung dengan melakukan praktikum titrasi asam basa Contoh-contoh untuk praktikum titrasi asam basa bisa didapat dari kehidupan sehari-hari, sehingga pembelajaran bersifat kontekstual. Pembelajaran akan lebih bermakna dengan melibatkan siswa secara langsung dalam proses pembelajaran sehingga pemahamankonsep siswa menjadi lebih baik.

Berdasarkan kesulitan yang dialami oleh siswa, maka yang dapat dilakukan agar pemahaman konsep siswa menjadi lebih baik yaitu pertama, guru dalam mengajar sebaiknya menggunakan beberapa cara mengajar sehingga pembelajaran tidak membosankan dan meningkatkan minat siswa dalam mempelajari kimia seperti kegiatan melakukan percobaan baik secara demonstrasi atau langsung melibatkan siswa secara langsung melakukan praktikum. Kedua, pemberian soal latihan yang bervariasi. Dalam pemberian soal-soal yang bervariasi akan membuat siswa terlatih dalam menyelesaikan berbagai soal pada materi titrasi asam basa.Ketiga, pendalaman konsep prasyarat dan penekanan konsep-konsep penting pada materi titrasi asam basa. Guru sebaiknya tidak melupakan konsep-konsep prasyarat agar konsep selanjutnya dapat dipahami secara baik oleh siswa seperti dalam menuliskan persamaan reaksi, jenis asam dan basa. Pembelajaran dapat pula dilakukan secara intertekstual sehingga siswa memahami materi secara makroskopis, mikroskopis, dan simbolik.

\section{SIMPULAN}

Berdasarkan hasil dan pembahasan dapat disimpulkan bahwa masih rendahnya pemahaman konsep siswa pada materi titrasi asam basa. Kesulitan pemahaman konsep yang dialami oleh siswa yaitu siswa kesulitan dalam menjelaskan pemilihan indikator, siswa kesulitan dalam menuliskan persamaan dan menyetarakan persamaan reaksi asam 
sulfat dan natrium hidroksida, siswa kesulitan dalam menentukan konsentrasi asam yang bervalensi dua sebanyak dan kesalahan siswa dalam menentukan konsentrasi asam dan basa bervalensi satu.Siswa tidak dapat menentukan jenis titrasi berdasarkan kurva dan siswa kesulitan dalam menentukan jenis zat pada setiap daerah. Guru dan siswa itu sendiri merupakan faktor yang menyebabkan rendahnya pemahaman konsep siswa. Menciptakan strategi pembelajaran yang bermakna dan tidak membosankan dapat menjadi solusi bagi guru untuk meningkatkan pemahaman siswa menjadi lebih baik.

\section{DAFTAR RUJUKAN}

Arifin, M., dkk. (2003). Strategi Belajar Mengajar Kimia. Bandung: Jurusan Pendidikan Kimia, FMIPA UPI.

Brousseau, G. (2002). Theory of didactical situations in mathematics. New York: Kluwer Academic Publishers.

Indrayani, P. (2013). Analisis pemahaman makroskopik, mikroskopik, dan simbolik titrasi asam-basa siswa kelas XI IPA SMA serta upaya perbaikannya dengan pendekatan mikroskopik. Jurnal Pendidikan Sains, 1(2), hlm 208-216.

Nahkleh, M., B. (1992). Why some student don't learn chemistry. Journal of Chemical Education, 69 (3), hlm.191-195.

Sheppard, K. (2006).High school students' understanding of titration and related acidbase phenomena. Chemistry Education Research and Practice, 7(1), hlm 32-45.

Sprenger, M. (2011). Cara mengajar agar siswa tetap ingat. Jakarta: Erlangga.

Windura, S. (2010). Memory champion at school. Jakarta: PT. Elex Media Komputindo. 